\title{
THE IMPACT OF ETHICS ON THE REGULATION OF MANAGERIAL ACTIVITY: CASE OF PUBLIC ORGANIZATIONS IN TUNISIA
}

\author{
Dr. Mohamed Karim AZIB \\ Assistant Professor, Faculty of Economics and Management Sciences of Tunis, \\ Tunis El Manar University, Tunisia.
}

Research Laboratory, Applied Research in Business Relationships and Economics, (ARBRE), University of Tunis, Tunisia

\begin{abstract}
The objective of this research work was to analyze and assess the impact of ethics on the regulation of managerial activity. The conceptual analysis was devoted to the study of the regulatory role of ethics and the influence of its determinants: the partners' expectations, the leader's exemplarity and the societal principles. The conceptual study was also dedicated to identifying the axes of regulation: the performance level, the manifested conduct and the mobilization of energies. The empirical analysis conducted with a sample of public organizations confirmed the decisive influence of ethics on the regulation of their managerial activity. The empirical results demonstrated that the influence of ethics on the axes of regulation is exerted through the leaders' exemplarity, in first position, and the societal principles, in second position.
\end{abstract}

Key words: Ethics, Managerial Activity, Regulation, Performance Level, Manifested Conduct, Mobilization of Energies, Leader's Exemplarity, Partners' Expectations, Societal Principles, Public Organizations

Cite this Article: Mohamed Karim AZIB, The Impact of Ethics on the Regulation of Managerial Activity: Case of Public Organizations in Tunisia, International Journal of Management, 11(12), 2020, pp 2273-2282.

http://iaeme.com/Home/issue/IJM?Volume=11\&Issue=12

\section{INTRODUCTION}

The managerial activity aims to create value for the organization and its partners. The managerial activity is deployed within an environment and is based on the design of decisions, the operational execution and the evaluation of the work performed. The managerial activity is the result of individual and collective work carried out in a well-defined 
ethical climate and which will be subject to steering and regulation to identify and correct significant deviations. The regulation of managerial activity is based on evaluation mechanisms and techniques, but also refers to the culture and ethics of the organization, which determine what kinds of managerial practices are accepted, tolerated or proscribed.

The choice of this theme leads to the formulation of this research question: what is the impact of ethics on the regulation of managerial activity? This research work will be dedicated to the analysis of the importance of ethics in the orientation of managerial activity, the study of the various influences that contribute to the determination of ethics with an emphasis on its regulatory role. The synthesis will allow the formulation of a research proposal with the associated hypotheses. This research proposal will be tested and validated, based on the presentation and interpretation of the empirical results of the survey conducted with a sample of public organizations.

\section{THE ETHICS AND THE MANAGERIAL PRACTICE}

The ethics determines the principles that govern action based on the sharing of guiding ideas $[1,44]$, the norms, values and customs that influence individual and organizational behavior shaped by collective action or inculcated as a result of an acculturation process $[2,3,4,50]$. The ethics aims to establish a climate of trust through fair treatment, exemplary managerial behavior and partnership-based governance that promotes social responsibility towards stakeholders. [5]. The business ethics promote managerial practices and operating methods that aim to balance results-oriented management with moral and deontological imperatives [6, $7,8]$. The ethics are implemented through conventions that define the operating rules to be respected and that regulate the organization's relationship with the actors in its environment [9] with the evaluation of the impact of the decisions and actions taken on the organization and its partners [10].

The ethical practices are linked to the organization's social responsibility, which has evolved from an approach focused on shareholder satisfaction and economic and financial objectives [11, 46] towards a more extended and global approach with a long-term perspective where the organization integrates all the interests and expectations of the stakeholders in the determination of objectives, decision-making, evaluation and regulation of managerial action [8].

The ethics is the expression of the wills, values, norms, professional practices and preferences of the various actors in the organization's immediate environment [12]. The ethics is determined by influences from stakeholders, leaders and societal culture [1, 13, 14, 33, 45].

\section{THE DIVERSITY OF ETHICS' DETERMINANTS}

\subsection{The Partners' Expectations}

The stakeholders are a "coalition of interests"; they exert a power of influence and regulation on organizations $[15,16]$. The stakeholders interact with the organization and may be affected by the organization's risks, decisions or outcomes [17, 18].

The stakeholders are interested by the organization's activity, they express their expectations and defend their interests; the quality of the organization's relationship with its partners affects its level of performance and value creation $[19,20]$.

\subsection{The Leaders' Exemplarity}

The leaders aim to realize their personal aspirations and the recognition by improving their socio-professional position, reputation, status and role in the organization [1]. They define the vision, ambitions and mobilize resources [12]. The leader's values system, preferences, 
personality and managerial behavior serve as a guide and example for the organization [21]. The leader coordinates, reconciles and arbitrates between the interests of the various stakeholders [22, 49, 51]. The leader has a power that allows him to recognize merit, sanction dysfunctions, issue directives, possess knowledge and constitute a relational network [23]. The managers-leaders are required to be socially responsible, diligent and to evaluate the economic and social consequences of their managerial action on stakeholders [4, 46]. The governance principles require them to be accountable for their actions during the entire managerial process and to justify their decisions $[8,46]$. The diversity of backgrounds and profiles of leaders explains the differentiation in the treatment of similar problematic situations $[22,48]$.

\subsection{The Societal Principles}

The societal culture is based on values and principles that influence and tend to converge individual and collective ways of thinking, perception, attitude and behavior [21, 43] but it evolves with diversity and conflict situations [24]. The societal culture and principles determine the nature of relationships with internal and external partners, promotes the transfer and the homogenization of knowledge, skills and references [12]. The collective dimension of the societal principles fosters cohesion and the sharing of a common frame of reference based on norms, objectives, interests, values and professional practices $[25,26]$; these frames of reference contribute to an informal and diffuse control, to the regulation of behaviors [8] and guide the reactions and the solutions in problematic situations [27]. The societal culture and principles are characterized by their diversity according to regions and countries. Consequently, practices that are accepted in one region may be outlawed in another. The levels of ethical requirements vary according to the institutional frameworks [21, 48].

\section{THE MODES OF ETHICAL REGULATION}

The practice of ethics is characterized by two main approaches [28, 29, 30, 31]. An approach based on utilitarianism, on the evaluation of the actions engaged and the responsibility, where the decision-maker must assess the extent and nature of the impact of the functioning of his organization on the stakeholders [32]. This approach aims to regulate the choice of objectives and the prevention of abusive behaviors that are sources of conflicts of interest $[3,30]$. The normative ethical approach is oriented towards values, moral rights and justice; this approach aims to consecrate fundamental principles in the regulation of managerial activity independently of any question of feasibility [3, 30]. The ethics contributes to the regulation of managerial activity through the demand for transparency, which promotes the clarification of decision-making processes and reduces information asymmetries for more balanced relationships and an evaluation based on sincere and reliable information. The ethics favors the establishment of a climate of trust through fair and regular practices and the security of transactions. The ethics aims to establish a mutually beneficial partnership for the organization and its partners. The non-respect of ethical rules may result in actions varying from disapproval to legal recourse $[13,14,33]$. The stakeholders aspire to a partnership and mutually beneficial transactional relationships with the organization (reciprocity); they demand to be informed about the decisions and actions that impact them (transparency) and to ensure that the management of the organizations is respectful of their rights and interests (regularity); the stakeholders assume a controlling role, express expectations, exert pressure, influence decision-makers, have bargaining power and can engage themselves in conflictual actions $[13,14,33]$. The managers leaders contribute to the regulation of the organization through the steering and information systems set up, which require sincere and reliable information (transparency); they act as coordinators and supervisors of the work accomplished by their teams (reciprocity) and the degree of exemplarity of their managerial 
behavior (regularity) determines the loyalty of the practices adopted [13, 14, 33]. The societal principles consecrate a referential that contribute to a better predictability of behaviors in a situation and to clarify the reasons for attitudes or behaviors manifested by managers (transparency); the societal principles determine the conditions of integration of an individual or an organization and allows us to understand the convergences and divergences that can exist in exchanges and interpersonal relationships (reciprocity); the societal principles contribute to the internalization of accepted, tolerated (regularity) or prohibited practices [13, $14,33]$.

\section{THE REGULATION AXES OF MANAGERIAL ACTIVITY}

The regulation is essential for the piloting and the mastery of the activity. The regulation is based on a systemic vision of the management of an organization with the possibility of coordination and mutual adaptation between the different components [12]. The regulation involves setting objectives, establishing measurable results, realizing benchmarks for comparison, identifying gaps and the possibility of initiating measures and changes to make progress [34]. The regulation can have several purposes: risk prevention, protection of assets and correction of malfunctions [35]. The regulation can be carried out in a "mechanical" way to control variations, to favor adjustments between two variables to reach an equilibrium; the regulation can also be "systemic" when it is necessary to evaluate the interactions between different components [36]. The regulation is "global" when it relates to the strategic management of the organization and its ability to evolve within its institutional framework; the regulation is "individual" because it concerns the integration and supervision of each human resource in the work team; this type of regulation is based on the evaluation of the superior, the involvement of the employee in decision-making and the application of legal and contractual dispositions. The "organic" regulation relates to the relationships and interdependencies between the various units and centers of responsibilities in an organization; this type of regulation is based on hierarchical relationships, compliance with rules and procedures, and the achievement of objectives in return for the decision-making autonomy allowed [12]. The regulation involves taking into consideration the level of performance achieved so that it can be measured, compared and positioned in relation to a referential to adjust significant deviations. The regulation influences, guides and enhances, positively or negatively, the individual and collective managerial commitment and course of action in order to respond to pressures and needs or to comply with the organization's internal and external standards, values and professional practices $[37,38,39,34,40]$. The regulation establishes the mechanisms of motivation and mobilization such as empowerment, participation, profitsharing, rewards and recognition that determine the levels of energy, perseverance and effort that an individual will expend in carrying out the work and achieving an objective $[1,34]$. The ethics, as a factor of regulation of the managerial activity, contribute to the determination of the type of results to be valorized, to show the desired behaviors and to the canalization of efforts and energies around visions, missions, objectives and values. The regulation can act on managerial activity in different ways: "preservation of the current situation", "adaptation to changes" or "deliberate change" [12, 13, 14, 33, 41].

\section{THE RESEARCH PROPOSAL AND THE FORMULATION OF THE HYPOTHESES}

The conceptual analysis leads to the formulation of a research proposal based on the impact of ethics on the regulation of managerial activity. The impact of ethics is determined by the partners' expectations, the leaders' exemplarity and the societal principles; the regulation of managerial activity is based on the performance level, the manifested conduct and the 
mobilization of energies [13, 14, 33]. This research proposal requires the formulation of the following hypotheses: The first hypothesis considers that the ethics has an impact on the regulation of managerial activity (H1); Three sub-hypotheses can be stated: the ethics has an impact on the regulation of the performance level (H1.1), on the manifested conduct (H1.2) and on the mobilization of energies (H1.3). The second hypothesis considers that the partners' expectations contribute to the regulation of the managerial activity $(\mathrm{H} 2)$; three sub-hypotheses can be envisaged: the partners' expectations exert an impact on the regulation of the performance level $(\mathrm{H} 2.1)$, on the manifested conduct $(\mathrm{H} 2.2)$ and on the mobilization of energies (H2.3). The third hypothesis considers that the leaders' exemplarity contributes to the regulation of the managerial activity; three sub-hypotheses can be proposed: the leaders' exemplarity has an impact on the regulation of the performance level $(\mathrm{H} 3.1)$, on the manifested conduct (H3.2) and on the mobilization of energies (H3.3). The fourth hypothesis considers that the societal principles contribute to the regulation of the managerial activity (H4); three sub-hypotheses can be explored: the societal principles have an impact on the regulation of the performance level (H4.1), on the manifested conduct (H4.2) and on the mobilization of energies (H4.3).

\section{THE EMPIRICAL METHODOLOGY}

This research work is based on a positive and hypothetico-deductive approach. The empirical analysis was based on a convenience sample of 67 public organizations operating in a public service activity; the survey targeted public managers by using a questionnaire based on the Likert scale with face-to-face interviews [42].

\section{THE EMPIRICAL RESULTS}

\subsection{The Empirical Validation of the items Proposed}

The validation of the items relating to the ethics and the regulation of managerial activity was realized with the reliability testing and the principal component analysis. The results enabling the validation of the ethics and its components are presented in the Table 1:

Table 1 The validation of the proposed items: The ethics and its components

\begin{tabular}{lllll}
\hline $\begin{array}{l}\text { Name of the extracted } \\
\text { component }\end{array}$ & $\begin{array}{l}\text { Cronbach's } \\
\text { Alpha }\end{array}$ & KMO & $\begin{array}{l}\text { Bartlett's } \\
\text { test }\end{array}$ & $\begin{array}{l}\text { Total Variance } \\
\text { Explained }\end{array}$ \\
\hline Partners' Expectations (PE) & 0,798 & 0,603 & 0,000 & 71,655 \\
\hline Leaders' Exemplarity (LE) & 0,838 & 0,677 & 0,000 & 76,158 \\
\hline Societal Principles (SP) & 0,887 & 0,747 & 0,000 & 82,040 \\
\hline Ethics (E) & 0,865 & 0,622 & 0,000 & 78,492 \\
\hline
\end{tabular}

The results allowing the validation of the regulation of the managerial action and its axes are exposed in the Table 2:

Table 2 The validation of the proposed items: the regulation of managerial activity and its components

\begin{tabular}{lllll}
\hline $\begin{array}{l}\text { Name of the extracted } \\
\text { component }\end{array}$ & $\begin{array}{l}\text { Cronbach's } \\
\text { Alpha }\end{array}$ & KMO & $\begin{array}{l}\text { Bartlett's } \\
\text { test }\end{array}$ & $\begin{array}{l}\text { Total Variance } \\
\text { Explained }\end{array}$ \\
\hline Performance Level (PL) & 0,627 & 0,531 & 0,000 & 61,060 \\
\hline Manifested Conduct (MC) & 0,8 & 0,621 & 0,000 & 75,487 \\
\hline Mobilization of Energies (ME) & 0,851 & 0,599 & 0,000 & 78,731 \\
\hline $\begin{array}{l}\text { Regulation of Managerial } \\
\text { Activity (RMA) }\end{array}$ & 0,951 & 0,763 & 0,000 & 91,120 \\
\hline
\end{tabular}

The validity of the measurement scale was confirmed by the results of Cronbach's Alpha; this allows to validate the internal coherence between the items proposed to evaluate the 
impact of ethics and its components (the partners' expectations, the leaders' exemplarity and the societal principles) on the axes of regulation of managerial activity (the performance level, the mobilization of energies and the conduct manifested). The factorial analysis (Varimax method) demonstrated the unidimensionality of the proposed variables; this analysis was based on the measure of sampling adequacy (KMO), the Bartlett's test of sphericity, significant $(\mathrm{sig}=0,000)$ in all the analyses performed and the total variance explained (extraction sums of squared loadings).

\subsection{The Evaluation of the Impact of Ethics on the Regulation of Managerial Activity of Public Organizations}

The analysis and the evaluation of the impact of ethics on the regulation of the managerial activity was carried out using simple and multiple linear regressions (stepwise method). All the models and the coefficients presented are significant $(\operatorname{sig}=0,000)$ with a "t of student" higher than 2. Concerning the collinearity test, the Tolerance is higher than 0.3 with the Variance Inflation Factor (VIF) less than 3.3 (in the case of multiple linear regressions). The results of the linear regressions (Table 3 ) confirm the positive impact of ethics $(t=11,264$; sig $=0,000)$ on the regulation of managerial activity in public organizations (validation of hypothesis H1).

Table 3 The evaluation of the influence of the ethics on the regulation of the managerial activity and its components (summary of significant models; sig. $=0,000$ )

\begin{tabular}{lc}
\hline \multicolumn{1}{c}{ Standardized coefficients } & Adjusted R Square \\
\hline $\mathbf{R M A}=0,813 \mathbf{E}+5,160 \mathrm{E}-17$ & 0,656 \\
\hline $\mathbf{P L}=0,762 \mathbf{E}+1,306 \mathrm{E}-16$ & 0,574 \\
\hline $\mathbf{M C}=0,752 \mathbf{E}+6,221 \mathrm{E}-17$ & 0,558 \\
\hline $\mathbf{M E}=0,816 \mathbf{E}+6,600 \mathrm{E}-17$ & 0,660 \\
\hline
\end{tabular}

The results of the linear regressions (Table 3 ) confirm the positive impact of the ethics on the axes of regulation of managerial activity. The ethics have the greatest influence on the mobilization of energies $(t=11,365$; sig $=0,000)$. The ethics contributes decisively to the regulation of the performance level, in second position $(\mathrm{t}=9,474$; $\operatorname{sig}=0,000)$, and to the regulation of the manifested conduct, in third position $(\mathrm{t}=9,187$; sig $=0,000)$. These results validate the hypotheses H1.1, H1.2 and H1.3.

The multiple linear regression results (Table 4) confirm the influence of the leaders' exemplarity, in first position $(\mathrm{t}=7,001$; $\mathrm{sig}=0,000$; Tolerance $=0,534 ; \mathrm{VIF}=1,874)$, and the societal principles, in second position $(\mathrm{t}=4,318$; $\operatorname{sig}=0,000$; Tolerance $=0,534$; VIF $=$ 1,874), as components of the ethics that have a determinant impact on the regulation of managerial activity in public organizations. These results validate the hypotheses $\mathrm{H} 3$ and $\mathrm{H} 4$.

Table 4 The evaluation of the impact of ethics' components on the regulation of managerial activity (summary of significant models; sig. $=0,000$ )

\begin{tabular}{rc}
\hline Standardized coefficients & Adjusted R Square \\
\hline RMA $=0,585$ LE $+0,361$ SP $+5,059 \mathrm{E}-17$ & 0,754 \\
\hline
\end{tabular}

The empirical analysis allowed to evaluate the influence of the components of ethics on each axis of the regulation of managerial activity of public organizations (Table 5). 
Table 5 The evaluation of the influence of ethics' components on the axes of regulation (summary of significant models; sig. $=0,000$ )

\begin{tabular}{lc}
\hline \multicolumn{1}{c}{ Standardized coefficients } & Adjusted R Square \\
\hline $\mathbf{P L}=0,410 \mathbf{L E}+0,508 \mathbf{S P}+9,840 \mathrm{E}-17$ & 0,702 \\
\hline $\mathbf{M C}=0,803 \mathbf{~ L E}+1,216 \mathrm{E}-16$ & 0,639 \\
\hline $\mathbf{M E}=0,576 \mathbf{L E}+0,361 \mathbf{S P}+6,377 \mathrm{E}-17$ & 0,739 \\
\hline
\end{tabular}

The results obtained reveal that the leaders' exemplarity exerts the most important influence on the manifested conduct $(\mathrm{t}=10,850 ; \mathrm{sig}=0,000)$ and the mobilization of energies $(\mathrm{t}=6,686 ; \mathrm{sig}=0,000$; Tolerance $=0,534 ; \mathrm{VIF}=1,874)$. The leaders' exemplarity influence is in second position concerning the regulation of the performance level $(t=7,001$; $\mathrm{sig}=0,000$; Tolerance $=0,534 ; \mathrm{VIF}=1,874$ ). The results confirm hypotheses H3.1, H3.2 and H3.3.

The societal principles have the most important influence on the performance level $(\mathrm{t}=$ 4.318; sig $=0,000$; Tolerance $=0,534 ;$ VIF $=1,874)$; the impact on the mobilization of energies is in second position $(\mathrm{t}=4,196$; $\mathrm{sig}=0,000$; Tolerance $=0,534$; VIF $=1,874)$. The results validate hypotheses H4.1 and H4.3; the hypothesis H4.2 is not confirmed. The results obtained indicated that the partners' expectations do not have a significant impact on the regulation of the managerial activity of the public organization. The hypotheses H2, H2.1, $\mathrm{H} 2.2$ and $\mathrm{H} 2.3$ are not validated.

\section{THE INTERPRETATION AND THE DISCUSSION OF THE RESULTS}

The results obtained have confirmed the impact of the ethics and part of its components on the regulation of the managerial activity of public organizations that carry out missions of general interest and public service based on principles such as legality, integrity, transparency, equality, responsibility and justice [51]. These ethical principles guide and contribute to the regulation of decision-making processes, implementation procedures and evaluation mechanisms. The ethics exert their influence through the vision and the degree of exemplarity of public leaders: political or administrative leaders [53]. The public organizations are means at the disposal of the public authorities to concretize their economic and social policy towards the realization of a social project based on norms, values and uses. The results reveal that the influence of stakeholders is not significant. In fact, the protected position of public organizations in the market, the mandatory nature of certain public services, the weight of hierarchy and the procedural functioning do not favor the involvement of stakeholders in the management of public organizations; this indicates the progress that still needs to be made for cognitive public organizations, open to the environment and networked through partnerships with the participation of stakeholders in the design, execution and evaluation of public services $[53,54,55,56]$.

\section{CONCLUSION}

The objective of this research work was to evaluate the influence of ethics on the regulation of managerial activity. The conceptual analysis led to propose the components of the ethics and the regulation of managerial activity. The empirical analysis demonstrated the decisive importance of the ethics in the regulation of public organizations' activity. Concerning the determinants of ethics, it is the influence of leaders' exemplarity that exerts an impact on all the axes of regulation: the manifested conduct (in first position), the performance level (in second position) and the mobilization of energies (in third position). The societal principles have an impact on regulation, through the mobilization of energies (in first place) and the level of performance (in second place). The influence of stakeholders' expectations was not significant; this result shows the changes that still need to be made in order to promote 
stakeholder participation in the governance and the management process of public services. This research work should be developed by analyzing the influence of stakeholders on the components of the operational functioning of public organizations.

\section{REFERENCES}

[1] Darbelet, M., Izard, L. and Scaramuzza, M. Notions fondamentales de management », Vanves: Foucher, 2004.

[2] Rojot, J. Déontologie et gestion des ressources humaines », Paris: Economica, 1992

[3] Louart, P. Ethique. In: Le Duff, R., ed., Encyclopédie de la gestion et du management », Paris: Dalloz, 1999., pp. 367-368.

[4] Rue, L. W. and Byars, L. L. Management: skills and application. Boston: Irwin McGraw-Hill, 2000 .

[5] Ballet, J. and De Bry, F. L'entreprise et l'éthique. Paris: Seuil, 2001.

[6] Le Net, M. La mobilisation éthique en affaires. L'influence de l'éthique des affaires sur la compétitivité de l'entreprise., Paris: Regards, Economica, 1992.

[7] Pasquero, J. Éthique des affaires, responsabilité sociale et gouvernance sociétale : démêler l'écheveau », Gestion, Revue Internationale de Gestion, 32(1), Spring 2007, pp. 112-116.

[8] Mercier, S. L'éthique dans les entreprises. Paris: La Découverte, Syros, 1999.

[9] Kerven, G. Y. Culture réseau: éthique et écologie de l'entreprise. Paris: ESKA, 1993.

[10] Solomon, R. and Hanson K. R. La morale en affaires, clé de la réussite », Paris: Editions d'Organisation, 1989.

[11] Friedman, M. The social responsibility of business is to increase its profits. New York: The New York Times Magazine, September 13, 1970, pp. 32-33, 122-126

[12] Capet, M., Causse, G. and Meunier, J. Diagnostic, organisation, planification d'entreprise: diagnostic et politique Générale. Volume 1, Paris: Economica, 1986.

[13] Azib, M. K. La coordination entre le cadre institutionnel et le système de gestion dans le management de l'entreprise : analyse comparative entre le secteur privé et le secteur public en Tunisie. Ph. D. Dissertation, Tunis: Faculty of Economics and Management of Tunis, 2012.

[14] Azib, M. K. and Frioui, M. The coordination between the institutional framework and the management system of the firm: comparative analysis between the public sector and the private sector in Tunisia. International Journal of Business and Management Studies, 4(2), 2012, pp. 117-128.

[15] Mintzberg, H. Le pouvoir dans les organisations. Paris: Editions d'Organisation, Editions Agence d'ARC, 1986.

[16] Cyert, R. M. and March, J.G. A behavioral theory of the firm. New Jersey: Englewood Cliffs, Prentice-Hall, 1963.

[17] Freeman, R. E. Strategic management: a stakeholder approach. Boston: Pitman-Ballinger, 1984.

[18] La Bruslerie, H. Le rôle de l'éthique du respect dans la déontologie économique et la gestion. Direction et Gestion des Entreprises, 164-165, 1998, pp. 73-86.

[19] Goodpaster, K. E. Business ethics and stakeholder analysis. Business Ethics Quaterly, 1, January 1991, pp. 53-73.

[20] Magakian, J.-L. 100 fiches pour comprendre la stratégie d'entreprise. Paris: Bréal, 2002. 
[21] Meier, O. Management interculturel. Stratégie, Organisation, Performance. Paris: Dunod, 2004.

[22] Mintzberg, H., Le pouvoir dans les organisations. Paris: Editions d'Organisation, 1986.

[23] Hesselbein, F. Hesselbein on Leadership. San Francisco: CA, Jossey-Bass, 2002

[24] Hatch, M. J. Théorie des organisations: de l'intérêt de perspective multiple. Paris: De Boeck Université, 2000.

[25] Fleury, J. La culture. Paris: Bréal, 2002

[26] Sims, R. The institutionalization of organiszational ethics. Journal of Business Ethics, 10(7), 1991, pp. 493-506.

[27] Trice, H. and Beyer, J. The culture of work organisations. New Jersey: Prentice Hall, 1993

[28] Cavanagh, G. E, Moberg, D. J. and Velasquez, M. G. The ethics of organizational behaviour. Academy of Management Review, 5, 1981.

[29] Brady, F. N. Ethical managing: rules and results. New York: Macmillan, 1990.

[30] Bergeron, P. G. La gestion dynamique: concepts, méthodes et applications », Québec: Gaëtan Morin, 2001.

[31] Klimsza, L. Business ethics. Introduction of the ethics of values. Lucjan Klimsza \& bookboon.com, 2014.

[32] Hoffman, W. M. and Moore J. M. Business ethics : readings and cases in corporate morality », New York: McGraw-Hill, 1990.

[33] Azib, M. K. The interaction between the components of the management system of the firm: a comparative analysis between public and private enterprises in Tunisia. International Journal of Business And Management Studies, 5(2), 2013, pp. 201-2013.

[34] Turgeon, B. and Lamaute, D. Le management dans son nouveau context. Montréal-Toronto: Chenelière/McGraw-Hill, 2002.

[35] Simon, H. E. Administration et processus de decision. Paris: Economica, 1983.

[36] Orange, G. Régulation. In: Le Duff, R., ed., Encyclopédie de la gestion et du management. Paris: Dalloz, 1999, pp. 1054-1055.

[37] Igalens, J. Comportement organisationnel. In: Le Duff, R., ed., Encyclopédie de la gestion et du management. Paris: Dalloz, 1999, pp. 160-161.

[38] Louart, P. Comportement. In: Le Duff, R., ed., Encyclopédie de la gestion et du management. Paris: Dalloz, 1999, pp. 155-156.

[39] Jones, G. R., George, J. M. and Hill, C. W. Contemporary Management. Boston: McGrawHiII, 2000.

[40] Vallerand, R. J., ed., Les fondements de la psychologie sociale. Montréal: Gaëtan Morin, 2006.

[41] Oliver, C. Strategic responses to institutional processes. Academy of Management Review, 16, 1991, pp. 145-180.

[42] Evrard, Y., Pras, B. and Roux, E. (in collaboration with. Choffray, J.-M., Dussaix A.-M., Claessens M.) Market, études et recherches en Marketing. Paris: Dunod, 2000.

[43] Hartman, L. P., DesJardins, J. and MacDonald, C. Business Ethics. Decision Making for Personal Integrity and Social Responsibility, New York: McGrawl Hill Irwin, 2014.

[44] LaRue, T. H. The Ethics of Management: A Multidisciplinary Approach. New York: McGrawl Hill Irwin, 2011. 
[45] Kolb, R W., ed., Encyclopedia of business ethics and society, London: Sage Publications, 2008.

[46] Crowther, D. and Aras, G. Corporate Social Responsibility. David Crowther \& Güler Aras \& bookboon.com, 2008.

[47] Devillard, O. and Rey, D. Culture d'entreprise: un actif stratégique. Efficacité et performance collective, Paris: Dunod, 2008.

[48] Morin, P. and Delavallée, E. Le Manager à l'écoute du sociologue, Paris : Editions d'Organisation, 2000.

[49] Blackburn, C. and Tétreault, S. Le manager au quotidien, $2^{\text {nd }}$ edition, Le Mans : Gereso, 2015.

[50] Alexandre-Bailly, F., Bourgeois, D., Gruère, J.-P., Raulet-Croset, N. and Roland-Lévy C., (with the contribution of Tran V.), Comportements humains \& management, Montreuil: Pearson, 2016.

[51] Ollivier, D. Le métier de manager, Paris: Eyrolles, 2016.

[52] OECD, Renforcer l'intégrité en Tunisie: l'élaboration de normes pour les agents publics et le renforcement du système de déclaration de patrimoine », OECD, 2014.

[53] Chevalier, G. (Preface by Igalens J.) Eléments de management public, le management public par la qualité. Paris: Afnor Editions, 2009.

[54] Thom, N. and Ritz, A. Le management public: Concepts innovants dans le secteur public. Lausanne: Presses Polytechniques et Universitaires Romandes, 2013.

[55] Cohen, A.-G. La nouvelle gestion publique », Paris: Gualino, 2012.

[56] Hindriks, J. (Preface by Gollier, C., foreword by Hilgers, J.) Gestion publique: Théorie et pratique, Brussels: De Boeck, 2012. 